\title{
AC 2012-4586: ENGINEERING AS A LIBERAL DISCIPLINE: TWO, THREE, OR FOUR CULTURES?
}

\section{Dr. Robert O. Grondin, Arizona State University, Polytechnic}

Robert Grondin has B.S., M.S. and Ph.D. degrees in electrical engineering from the University of Michigan. He joined the faculty of Arizona State University in 1983, serving first in the Department of Electrical Engineering in the Fulton Schools of Engineering on ASU's Tempe campus and more recently in the Department of Engineering of the College of Technology and innovation on ASU's Polytechnic campus. 


\title{
Engineering as a Liberal Discipline:
}

\author{
Two, Three or Four Cultures?
}

In this paper we revisit an old question. How does engineering fit in among the various academic disciplines? While engineering is both an academic and a real-world task, here we will be concerned with its fit into the modern university, although we will note that the real-world of engineering activity does affect its fit into the university. We will start by reminding ourselves about the history of academic disciplines in general as it reveals some complexity to the question of the nature of an academic discipline. The meat of the paper will involve the application of a recent framework that the psychologist Jerome Kagan ${ }^{1}$ used to explore the relationship between the three major branches of the liberal arts, those being natural science, social science and the humanities. En route we will discover sufficient differences between engineering and natural science to justify a conclusion that these are two genuinely different academic activities. In particular, engineering involves more than just applying mathematics and science. We close with comments about engineering as a liberal discipline.

\section{The Birth of Academic Disciplines}

Kagan entitled his book The Three Cultures as he was inspired by C. P. Snow's famous lecture The Two Cultures ${ }^{2}$ in which Snow compared natural scientists with literary scholars. Snow's choice of words is significant. Instead of speaking of cultures, he could have spoken of disciplines. That would have been the more conventional choice. Discussions of this general topic often use the word discipline and then assume that the disciplines are defined in an epistemological manner.

Epistemology however did not drive the historical development of the various academic disciplines. In antebellum America, colleges were small, with several hundred students being viewed as a large enrollment. The antebellum college usually offered just one degree, a B.A. degree, which was implemented by a lock-step curriculum focused on classical studies. (Science was a recent addition.) There were no departments and no disciplines. Faculty reported directly to the President and were generally hired not because of any particular individual intellectual specialization but rather because they were literate in Greek and Latin and conversant with the literature of antiquity. There was no system of tenure and faculty were not viewed as professional scholars. This model of a classical education for all was abandoned in the fifty years that followed the Civil War. That fifty years was a period in which society which was undergoing both industrialization and urbanization and significant debates about the structure and purpose of a college education were common. Most of the various disciplines that still dominate the American college scene were established in this period. Comprehensive discussions of this evolution in American colleges can be found elsewhere. ${ }^{3}$ 
While epistemology plays a role in their definition, the disciplines were originally created and continue to survive because they fulfill various social needs. A more complex society has a need for people possessing specific intellectual skills and a vocabulary in which academic credentials roughly describe such skills is very useful. As colleges became much larger institutions, they were better able to provide a suite of such credentials at the point of graduation. This in turn helped generate need for faculty who were scholars learned in a field of specialization. Schools needed easy ways to recognize such scholars and as a result a framework for the credentialing of scholarly professionalization was established via doctorate programs, societies, journals and conferences. Furthermore, the increased size of the college and the greater range for activities generated an administrative need for some form of academic middle management that could be met by departments organized to match these specialties. This utility of the disciplines to society, universities and professors is a very important part of any discussion of the disciplines.

Louis Menand ${ }^{6}$ summarizes this nicely.

"The academic disciplines do not carve knowledge at the joints and they did not drop down out of God's blue sky. The disciplines were constructed at a particular historical moment, and teachers and students in the twenty-first century university are the heirs of that moment."

This same period saw the creation of formal college-level education in engineering. At the beginning of the antebellum period there were no engineering programs in an American college. While they had recently begun formal schooling in engineering in France, the English still followed an apprenticeship model. Furthermore, the English still generally viewed engineering as a manual trade. Leading British universities did not teach engineering. As the American antebellum college was greatly influenced by the English model, the antebellum colleges normally excluded engineering, and when they did include it, they sometimes assigned it a visibly lower status than the liberal arts. Well into the $20^{\text {th }}$ century, a large fraction of American engineers entered the profession through an apprenticeship.

Yet, there was a problem. Governmental and business leaders perceived a need for more engineers. A shortage of engineers of course also meant that there was a shortage of people to master apprentices. Starting with Washington's efforts to create a school for military engineers at West Point, there were efforts to create engineering schools. This tendency starts in the antebellum and then accelerates after the Civil War with the Morrill Land Grant Act which explicitly recognized "the mechanic arts" as a central target for the educational programs of a land grant university. Indeed, while few land grant universities are found among lists of leading liberal arts institutions, they play a prominent role in lists of leading engineering schools ${ }^{4}$. One consequence of this is that in terms of chronology, formal education in engineering at the undergraduate level came into being before the profession was well-organized in the United States. As the just quoted phrase "mechanic arts" suggests, the term "mechanical engineer" was still somewhat uncommon in the 1860’s. Terms such as electrical engineer or chemical engineer 
or industrial engineer were coined during the just described fifty year period in which academic disciplines were being created and defined. The long term effect on engineering education of this is that while most professions such as medicine and law are taught in separate graduate schools operated by practicing professionals with only loose control by their home institutions, engineering is an undergraduate program of study whose faculty often pursue a totally academic career in which direct professional practice plays a small role. Comprehensive discussions of this history can be found elsewhere. ${ }^{5}$

This complexity in which the concept of an academic discipline is both epistemological and sociological, where the university is in fact connected with the world and affected by general societal trends, is part of the attraction of Snow's choice of the word "culture”. Snow's lecture in fact was not principally about universities and academics but rather was focused on the far more important problem of the split of the world into rich countries and poor countries. One of the reasons why The Two Cultures sparked interest is that Snow argued that science is more important than literary scholarship in fostering a transition from poverty to wealth. Several years later in his essay A Second Look ${ }^{2}$, he expressed regret that the title The Two Cultures was not the best description of what his lecture actually was about.

Kagan is more focused on the university and on the life lived by a college professor. He felt that Snow's concept needed modernizing not because the epistemological distinctions between science and literary scholarship had changed but rather because since Snow's lecture we had seen the growth of big science and externally funded research with visible impact on the social structures of the university. Additional considerations for the modernization were that Snow had ignored social science, and that since Snow's time the humanities had experienced its own internal epistemological crisis of faith. As a result of such trends, Kagan believes that the university of today provides a very different atmosphere for scholarly activity than it did in Snow's time.

In this paper we will use Kagan's framework, which explicitly retains the mixing of epistemological and social concerns implicit in Snow's use of the word culture, as the basis for a similar exploration of the relationship between engineering and the liberal arts. We start with a brief review of that framework.

\section{Kagan's nine dimensions}

Kagan followed Snow's lead and used the word culture in his thoughts. He broke this down into nine dimensions, some of which are epistemological and some of which are social. The epistemological dimensions are:

- primary interest;

- $\quad$ sources of evidence and degree to which they are controlled;

- primary vocabulary and degree to which concepts are contextualized; 
The social dimensions are:

- degree of influence of social conditions produced by historical contingencies;

- degree to which ethical concerns influence questions and conclusions;

- degree of dependence on financial support from government and industry;

- likely size of collaborative teams;

- importance to national economy;

- criteria by which work is judged to be beautiful.

He then used these dimensions to compare and contrast natural science, social science and the humanities by constructing a table in which the nine dimensions are the rows and the three cultures are the columns. We reproduce it here as Table 1. All the wording is direct from Kagan.

Table 1. Kagan's comparison of the three cultures (natural science, social science and the humanities).

\begin{tabular}{|l|l|l|l|}
\hline Dimension & Natural science & Social science & Humanities \\
\hline $\begin{array}{l}\text { Primary } \\
\text { interests }\end{array}$ & $\begin{array}{l}\text { Prediction \& } \\
\text { explanation of } \\
\text { all natural } \\
\text { phenomena }\end{array}$ & $\begin{array}{l}\text { Prediction \& } \\
\text { explanation of } \\
\text { human behaviors } \\
\text { and } \\
\text { psychological } \\
\text { states }\end{array}$ & $\begin{array}{l}\text { An understanding of human } \\
\text { reactions to events and the } \\
\text { meaning humans impose on } \\
\text { experience as a function of } \\
\text { culture, historical era, and life } \\
\text { history }\end{array}$ \\
\hline $\begin{array}{l}\text { Sources of } \\
\text { evidence and } \\
\text { control of } \\
\text { conditions }\end{array}$ & $\begin{array}{l}\text { Experimentally } \\
\text { controlled } \\
\text { observations of } \\
\text { material } \\
\text { entities }\end{array}$ & $\begin{array}{l}\text { Behaviors, } \\
\text { verbal } \\
\text { statements, and } \\
\text { less often } \\
\text { biological } \\
\text { measures } \\
\text { gathered under } \\
\text { conditions in } \\
\text { which contexts } \\
\text { cannot always be } \\
\text { controlled }\end{array}$ & $\begin{array}{l}\text { Written texts and human } \\
\text { behaviors gathered under } \\
\text { conditions of minimal control }\end{array}$ \\
\hline
\end{tabular}




\begin{tabular}{|c|c|c|c|}
\hline Dimension & Natural science & Social science & Humanities \\
\hline $\begin{array}{l}\text { Primary } \\
\text { vocabulary }\end{array}$ & $\begin{array}{l}\text { Semantic and } \\
\text { mathematical } \\
\text { concepts } \\
\text { whose } \\
\text { referents are } \\
\text { the material } \\
\text { entities of } \\
\text { physics, } \\
\text { chemistry and } \\
\text { biology, } \\
\text { assumed to } \\
\text { transcend } \\
\text { particular } \\
\text { settings }\end{array}$ & $\begin{array}{l}\text { Constructs } \\
\text { referring to } \\
\text { psychological } \\
\text { features, states } \\
\text { and behaviors of } \\
\text { individuals or } \\
\text { groups, with an } \\
\text { acceptance of the } \\
\text { constraints that } \\
\text { the context of } \\
\text { observation } \\
\text { imposes on } \\
\text { generality }\end{array}$ & $\begin{array}{l}\text { Concepts referring to human } \\
\text { behavior, and the events that } \\
\text { provoke them with serious } \\
\text { contextual restrictions on } \\
\text { inferences }\end{array}$ \\
\hline $\begin{array}{l}\text { The influence of } \\
\text { historical } \\
\text { contingencies }\end{array}$ & Minimal & Modest & Serious \\
\hline $\begin{array}{l}\text { Ethical } \\
\text { influence }\end{array}$ & Minimal & Major & Major \\
\hline $\begin{array}{l}\text { Dependence on } \\
\text { outside support }\end{array}$ & $\begin{array}{l}\text { Highly } \\
\text { dependent }\end{array}$ & $\begin{array}{l}\text { Moderately } \\
\text { dependent }\end{array}$ & Relatively independent \\
\hline $\begin{array}{l}\text { Work } \\
\text { conditions }\end{array}$ & $\begin{array}{l}\text { Both large and } \\
\text { small } \\
\text { collaborations }\end{array}$ & $\begin{array}{l}\text { Small } \\
\text { collaborations } \\
\text { and solitary }\end{array}$ & Solitary \\
\hline $\begin{array}{l}\text { Contribution to } \\
\text { the national } \\
\text { economy }\end{array}$ & Major & Modest & Minimal \\
\hline $\begin{array}{l}\text { Criteria for } \\
\text { beauty }\end{array}$ & $\begin{array}{l}\text { Conclusions } \\
\text { that involve the } \\
\text { most } \\
\text { fundamental } \\
\text { material } \\
\text { components in } \\
\text { nature inferred } \\
\text { from evidence } \\
\text { produced by } \\
\text { machines and } \\
\text { amenable to } \\
\text { mathematical } \\
\text { descriptions. }\end{array}$ & $\begin{array}{l}\text { Conclusions that } \\
\text { support a broad } \\
\text { theoretical view } \\
\text { of human } \\
\text { behavior. }\end{array}$ & $\begin{array}{l}\text { Semantically coherent } \\
\text { arguments described in elegant } \\
\text { prose. }\end{array}$ \\
\hline
\end{tabular}




\section{Pure science, applied science and engineering}

We now turn our attention to the primary subject of this paper and consider how we can fit engineering into this framework. We start by asking about the relationship between engineering and natural science.

What did Kagan and Snow say about this relationship? Engineering is not directly addressed by Kagan but his description of the envy directed towards the natural scientists by the members of his other two cultures describes that envy as being based in part on the general public's belief that the research products of natural science have "reduced disease burdens, prolonged life, lightened manual labor, eased communication and travel, and contributed to national economies.” Engineering clearly is involved here. In a follow-on essay entitled A Second Look, Snow ${ }^{2}$ explained that he had considered a framework in which engineering and applied science would have been separated from "pure” science but had rejected it, choosing instead to include engineering in the natural science culture. He asserted that while he understood the reasons for such a split, and indeed had professed it himself at some point, he saw too much similarity between the methods of pure scientists and technologists. He described the relationship between pure and applied science as one of the "deepest problems in scientific history" and worried about the effect of introducing such a split. I believe that when both Snow and Kagan clump engineering in with natural science, they each provide an example of a broad failure to distinguish engineering from natural science.

This broad confusion between engineering and applied science is one that others have commented on. A recent report of the National Academy of Engineering summarizes a marketing study of the public image of engineering with the note that

"The public understanding of engineering is strongly linked to just one aspect of the discipline - the need for mathematics and science skills. Other vital aspects of engineering, such as creativity, teamwork and communication, are largely unknown.”7

Others worry that engineering professors themselves may not fully understand it. For example,

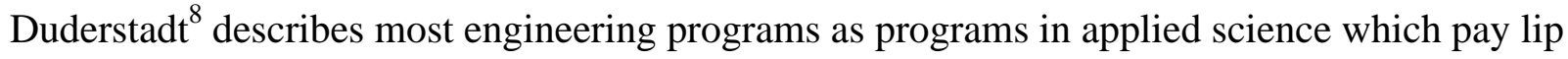
service to design, technical writing, and professional ethics to gain accreditation.

A first step towards understanding the differences between engineering and applied science is made by examining the motivations of engineers and scientist. For example, when Snow clumped science in with technology he was then forced to assert that there are two motives for science:

- $\quad$ understanding the natural world;

- controlling the natural world. 
However, discussions of either the history of science or the philosophy of science rarely include that second motive. All the attention is placed on understanding the natural world. For example, Kagan's description of the primary interest of scientists reflects just the motive of understanding the world. Snow himself characterized the reaction of pure scientists towards applied science and engineering as being "dimwitted" and criticized them for failing to recognize that applied questions could require first-rate intellectual efforts.

Scientists are intelligent people and we should take them at their word when they give primacy to the understanding of the natural world in their definition of their domain of activity. Here we will choose to separate engineering from science and explore the consequences of this difference in motive. That does not mean though that there isn't an overlap or similarity between science and engineering that needs exploration. We will use Kagan's approach to outline this similarity.

Kagan notes that there are four commonly used referents for the word "truth", these being:

- consensus on observation;

- logical or mathematical consistency;

- coherency in meaning between two or more sematic networks;

- a compelling feeling.

He notes that natural scientists clearly prefer the first two, social scientists the first and the third and humanists the last two. Engineers also prefer the first two. This leads to similarity between engineering and science. Kagan also notes that there are three main approaches used by scholars to construct a representation of something in which they have interest, these three being:

- Mathematics;

- Semantic networks;

- Perceptually-based schematic representations.

While all three of Kagan's cultures are capable of using all three representations, it is well known that mathematics works very well in the domain of physical science and becomes less effective as we move away from that domain. Engineers again generally find that mathematics is an effective representational tool for much of their work. So, both engineers and physical scientists use mathematical representations. However, these similarities in the notion of truth and the value of mathematics do not compel a conclusion that one discipline is a subset of the other. They may be using similar representations and similar definitions of truth while dealing with disparate questions.

These similarities are related to the fact that both engineers and scientists are interested in material entities. However the difference in motivation causes them to ask profoundly different 
questions about material entities. While both scientists and engineers are viewed as "fact" oriented individuals, one might say that they are interested in different types of facts. Using the terminology of the philosopher John Searle ${ }^{9}$, scientists are seeking brute facts while engineers are inexplicably involved with the construction of institutional facts. What is the difference between these two types of fact? Consider the chair in your office. If all humans disappeared tomorrow, leaving that chair behind, would that material object still be a chair? On the other hand, if all of humanity suddenly disappeared, the Sun would still be the same distance from Earth. Searle therefore sees us as having two different types of facts. There are brute facts whose truth does not depend on humans constructing social systems. Then there are institutional facts that depend on humans constructing social systems. Following Searle just a little further, a key difference between engineering and science then becomes intentionality. Both are concerned with an understanding of the material entities around us but engineers are concerned with aspects of those entities that arise from human intentions. Searle tells us that what makes a material entity a chair in part is that we intend to sit on it. It is this intentionality that transforms material entities into technology and art, which brings material entities into our social construction of reality. Engineers are focused on this intentionality while scientists are not.

This difference in focus is the reason why the subject matter overlap between science and engineering is smaller than some may realize. In actuality, most engineering students do not study that much science. The ABET accreditation requirement is for $25 \%$ of the 4 -year degree to be mathematics and sciences and most programs sit just barely above that goal, and very commonly there is more mathematics than science in this curricular block. To use my home institution as an example, some engineering students take as few as 3 courses in science. The university requires 2 science courses for everybody, including poets. 5 courses in science would be about the maximum required for any engineering degree at my institution. This is still below the level of a science minor and well short of the 15 or more science courses taken by a science major. Engineering students spend much more time in engineering courses than they do in science courses.

What is happening in these engineering courses is that the students are learning the primary vocabulary of engineering. Mathematics enters the vocabulary as we have already noted. Some science is needed as we do incorporate some of the vocabulary of science into the vocabulary of engineering to assist us in the description of material things. Concepts such as force, mass and energy are part of the engineering vocabulary. However, engineers spend most of their time exploring technology, and most of the curriculum is devoted to an introduction of the primary vocabulary and concepts used by engineers to describe technological systems and artifacts. This vocabulary and content is intimately related to the functions that we intend to accomplish with these systems and artifacts and is generally different from that of natural science. The intentionality associated with material entities permeates the primary vocabulary of engineering.

Do engineers "apply" science? Of course they sometimes do, but it is important to remember that reinventing the wheel is viewed as very poor engineering. Technology, not science, ends up 
being the most common starting point when engineers attempt to conceptualize a technological means to satisfying human intentions. Engineers sometimes realize that a scientific advance has occurred and attempt to figure out how that advance might be used. However, once some engineer has done this, the result becomes part of the vocabulary of engineering and this end result becomes the new starting point for future engineering activity. If you approach an engineering problem using only the primary vocabulary of science, you are probably doing it the long and hard way.

\section{Kagan's nine dimensions applied to engineering}

With that background established, let's quickly outline how engineering might be described in terms of Kagan's nine dimensions. We have already dealt with the first dimension, that of primary interest.

The second dimension has to do with sources of evidence. Here we realize that engineers often perform projects that run for months or years, and that different questions are asked at different stages of a project. Generally, the first step of a project requires engineers to understand the intentions of the humans who will be affected by the project. Evidence of the sort normally sought by social scientists and humanists plays important roles in this early stage. The evidence here may be heavily contextualized as well. Then, as engineers move into the middle phases of the project, the crucial evidence becomes comparisons of the behavior of technological entities against the intended behavior. Controlled experimentation and numerical modeling play important roles here. The last stage of engineering work however is the long-term evaluation of technology. Much of the evidence used here comes in the form of data collected in the field, where something far short of a controlled experiment occurs. Perhaps the most dramatic example of this is the analysis of accidents and catastrophes, sometimes referred to as forensic engineering.

While this project orientation is clearly true for the practicing professional, it does not provide as accurate of a picture of engineering inside the academy. Engineering curricula usually focus almost totally on the mid-portions of the above project cycle, and this happens to be the portion of the cycle in which the similarities between engineering and natural science are the most pronounced.

The third dimension is that of primary vocabulary. We have already partially discussed this. A concern of Kagan's that we did not refer to though is contextualization. Does the discipline struggle with the prospect that the same word or phrase or image is interpreted differently in different contexts? The extremes probably are theoretical physics on one hand and poetry on the other. The primary vocabulary of engineering is not heavily contextualized in this sense.

The fourth dimension is historical contingency. Kagan notes that there are two very different historical sequences at play in his analysis. A historical sequence sometimes referred to as "deep time” that plays out over billions of years is the historical sequence of interest in science. 
Humans play very little role in this sequence. The second sequence though is the one of interest in social science and the humanities, a sequence of perhaps 10,000 years duration, a sequence in which humans play a crucial role. This second sequence is the one of importance in engineering. The solutions that are developed by engineers depend on the current state of technology, and upon past events. Nuclear reactor design for example will probably be affected by the events that followed the recent Japanese tsunami. Other issues associated with compatibility with widely used systems, e.g. the QWERTY keyboard often play key roles. More importantly though, the type of historical contingencies considered by Kagan appears in engineering work during the early phases of a project, where the issue of what it is that we wish of accomplish is the central question of interest. In this regard engineering is more similar to social science than it is to natural science or the humanities.

The fifth dimension is ethics, and it is impossible to have a field be strongly linked to human intentions and concerns without having ethics play a major role. Here again it would seem that engineering is more similar to social science than it is to natural science.

The next several dimensions are the dependence on government and business for financial support, the size of collaborative efforts and importance to the economy. Here, engineering is very similar to the natural sciences. It is worth remembering that Kagan generally is discussing college professors, and the conclusion here is that the life of an engineering professor much more closely resembles that of a colleague in the sciences than it does the rest of liberal arts.

We then come to the criteria for beauty. Since we have been comparing engineering most closely with natural science, it is interesting that one can get the science "right" and still produce technology that others just don't see the need for, or technology that drives users crazy, or technology that immediately provokes the "not in my backyard” reaction. The criteria used to judge the beauty of the result of engineering activity have very little to do with science. This is another area where it is worth asking about contextualization. Individual human beings and human communities often have fairly unique reactions to certain types of technology. Context clearly matters in that regard. However, Kagan is referring to the criteria used by practitioners of the discipline. Engineers generally look for a fairly similar list of qualities in determining if a technological artifact is a beautiful piece of engineering. We use such a list here as our description of the engineering criteria for beauty.

\section{Design and professionalism - two new dimensions}

Our discussion leads us to consider possible new dimensions for the table. The first that we will consider is design. Design can be broadly defined as the intentional arrangement of energy and matter in space and time. While design is central to engineering, it does not belong to engineering. There are fashion designers, landscape designers, industrial designers, set designers, interior designers, urban designers etc. It has even been suggested that if we were to produce a new set of seven liberal arts for the twenty first century, design would be one of these seven $^{10}$. Design therefore is added as tenth dimension here. 
Design plays little role in natural science and in social science. The relationship between design and the humanities though is more complex. Although Kagan defines the humanities as consisting of literary scholars, there is a great deal of interaction between the humanities and the fine arts. These literary scholars are often dealing with hermeneutics, the interpretation and understanding of both verbal and non-verbal expressions. They also commonly deal with the history of art, architecture, music and film. The issue of the intentions of the creators of various physical objects and spaces therefore plays a role in the humanities, and discussions of the processes used in the design of the human-made environment in which we live are important in the scholarship associated with the humanities. Because of this, design does play a modest role in the humanities. If we were to add a column for the fine arts to the table, design would be of major importance in that column.

A second new dimension that is needed is the dimension of professional or vocational education. Clearly, engineering differs from Kagan's three cultures in that it is virtually universally viewed as an education intended to produce a practitioner of a profession largely practiced outside of the university setting. Inside engineering, this causes us to interact fairly closely with industry in defining overall program goals and objectives. Engineering units commonly have industrial advisory boards whereas most liberal arts units do not. Engineers also tend to conceptualize the curricula differently. The liberal arts view of college as an exploration by the student, as an experience in which the student learns about them self, what they are enjoy most and excel at, with an eye to a broad preparation for life, is not emphasized in the curricular thinking of engineering faculty. Engineering faculty tend to employ a pipeline metaphor, in which the student somehow has decided that they wish to become an engineer before they start taking engineering courses. We then worry about keeping them in the pipeline. Our curricular thinking also tends to assume that the only goal a student pursues as they leave the pipeline with a degree is that of professional practice as an engineer. While we love to tell students that an engineering degree is an excellent preparation for other professions such as law or medicine, the possibility that the degree should prepare the graduate for a broad set of post-baccalaureate opportunities not necessarily limited to engineering plays little role in the curricular design. This reliance on a pipeline metaphor may play a significant role in the huge disparity between engineering and most other college majors in the demographic of in-migration of students from other majors $^{11}$.

The final result is the expanded table that we provide in Table 2. 
Table 2. Kagan's comparison of the three cultures (natural science, social science and the humanities) extended to include engineering.

\begin{tabular}{|l|l|l|l|l|}
\hline Dimension & Engineering & $\begin{array}{l}\text { Natural } \\
\text { science }\end{array}$ & $\begin{array}{l}\text { Social } \\
\text { science }\end{array}$ & Humanities \\
\hline Primary interest & $\begin{array}{l}\text { Creation, } \\
\text { development } \\
\text { and } \\
\text { deployment } \\
\text { of material } \\
\text { entities } \\
\text { imbued with } \\
\text { utilitarian } \\
\text { intentionality }\end{array}$ & $\begin{array}{l}\text { Prediction \& } \\
\text { explanation } \\
\text { of all natural } \\
\text { phenomena }\end{array}$ & $\begin{array}{l}\text { Prediction } \\
\text { \& } \\
\text { explanation } \\
\text { of human } \\
\text { behaviors } \\
\text { and } \\
\text { psycho- } \\
\text { logical } \\
\text { states }\end{array}$ & $\begin{array}{l}\text { An under- } \\
\text { standing of } \\
\text { human } \\
\text { reactions to } \\
\text { events and } \\
\text { the meaning } \\
\text { humans } \\
\text { impose on } \\
\text { experience } \\
\text { as a } \\
\text { function of } \\
\text { culture, } \\
\text { historical } \\
\text { era, and life } \\
\text { history }\end{array}$ \\
\hline
\end{tabular}




\begin{tabular}{|c|c|c|c|c|}
\hline Dimension & Engineering & $\begin{array}{l}\text { Natural } \\
\text { science }\end{array}$ & $\begin{array}{l}\text { Social } \\
\text { science }\end{array}$ & Humanities \\
\hline $\begin{array}{l}\text { Sources of } \\
\text { evidence and } \\
\text { control of } \\
\text { conditions }\end{array}$ & $\begin{array}{l}\text { Social and } \\
\text { humanistic } \\
\text { evidence } \\
\text { gathered to } \\
\text { describe our } \\
\text { technological } \\
\text { intentions. } \\
\text { Comparison } \\
\text { of the } \\
\text { behavior of } \\
\text { material } \\
\text { constructs } \\
\text { and software } \\
\text { with this } \\
\text { intended } \\
\text { behavior. } \\
\text { Long-term } \\
\text { observation } \\
\text { of } \\
\text { performance } \\
\text { in actual } \\
\text { settings } \\
\text { which are not } \\
\text { controlled. }\end{array}$ & $\begin{array}{l}\text { Experi- } \\
\text { mentally } \\
\text { controlled } \\
\text { observations } \\
\text { of material } \\
\text { entities }\end{array}$ & $\begin{array}{l}\text { Behaviors, } \\
\text { verbal } \\
\text { statements, } \\
\text { and less } \\
\text { often } \\
\text { biological } \\
\text { measures } \\
\text { gathered } \\
\text { under } \\
\text { conditions } \\
\text { in which } \\
\text { contexts } \\
\text { cannot } \\
\text { always be } \\
\text { controlled }\end{array}$ & $\begin{array}{l}\text { Written } \\
\text { texts and } \\
\text { human } \\
\text { behaviors } \\
\text { gathered } \\
\text { under } \\
\text { conditions } \\
\text { of minimal } \\
\text { control }\end{array}$ \\
\hline $\begin{array}{l}\text { Primary } \\
\text { vocabulary }\end{array}$ & $\begin{array}{l}\text { Semantic \& } \\
\text { mathematical } \\
\text { concepts } \\
\text { whose } \\
\text { referents are } \\
\text { desired } \\
\text { utilitarian } \\
\text { functions and } \\
\text { complex } \\
\text { material } \\
\text { constructs } \\
\text { and software, } \\
\text { intended to } \\
\text { perform } \\
\text { these } \\
\text { functions. } \\
\text { Minimal } \\
\text { contextual } \\
\text { restrictions. }\end{array}$ & $\begin{array}{l}\text { Semantic } \\
\text { and } \\
\text { mathematical } \\
\text { concepts } \\
\text { whose } \\
\text { referents are } \\
\text { the material } \\
\text { entities of } \\
\text { physics, } \\
\text { chemistry } \\
\text { and biology, } \\
\text { assumed to } \\
\text { transcend } \\
\text { particular } \\
\text { settings }\end{array}$ & $\begin{array}{l}\text { Constructs } \\
\text { referring to } \\
\text { psycho- } \\
\text { logical } \\
\text { features, } \\
\text { states and } \\
\text { behaviors } \\
\text { of } \\
\text { individuals } \\
\text { or groups, } \\
\text { with an } \\
\text { acceptance } \\
\text { of the } \\
\text { constraints } \\
\text { that the } \\
\text { context of } \\
\text { observation } \\
\text { imposes on } \\
\text { generality }\end{array}$ & $\begin{array}{l}\text { Concepts } \\
\text { referring to } \\
\text { human } \\
\text { behavior, } \\
\text { and the } \\
\text { events that } \\
\text { provoke } \\
\text { them with } \\
\text { serious } \\
\text { contextual } \\
\text { restrictions } \\
\text { on } \\
\text { inferences }\end{array}$ \\
\hline
\end{tabular}




\begin{tabular}{|c|c|c|c|c|}
\hline Dimension & Engineering & $\begin{array}{l}\text { Natural } \\
\text { science }\end{array}$ & $\begin{array}{l}\text { Social } \\
\text { science }\end{array}$ & Humanities \\
\hline $\begin{array}{l}\text { The influence of } \\
\text { historical } \\
\text { contingencies }\end{array}$ & Modest & Minimal & Modest & Serious \\
\hline $\begin{array}{l}\text { Ethical } \\
\text { influence }\end{array}$ & Major & Minimal & Major & Major \\
\hline $\begin{array}{l}\text { Dependence on } \\
\text { outside support }\end{array}$ & $\begin{array}{l}\text { Highly } \\
\text { dependent }\end{array}$ & $\begin{array}{l}\text { Highly } \\
\text { dependent }\end{array}$ & $\begin{array}{l}\text { Moderately } \\
\text { dependent }\end{array}$ & $\begin{array}{l}\text { Relatively } \\
\text { independent }\end{array}$ \\
\hline $\begin{array}{l}\text { Work } \\
\text { Conditions }\end{array}$ & $\begin{array}{l}\text { Both large } \\
\text { and small } \\
\text { collabora- } \\
\text { tions }\end{array}$ & $\begin{array}{l}\text { Both large } \\
\text { and small } \\
\text { collabora- } \\
\text { tions }\end{array}$ & $\begin{array}{l}\text { Small } \\
\text { collabora- } \\
\text { tions and } \\
\text { solitary } \\
\text { scholars } \\
\end{array}$ & $\begin{array}{l}\text { Solitary } \\
\text { scholarship } \\
\text { is the norm }\end{array}$ \\
\hline $\begin{array}{l}\text { Contribution to } \\
\text { the national } \\
\text { economy }\end{array}$ & Major & Major & Modest & Minimal \\
\hline $\begin{array}{l}\text { Criteria for } \\
\text { beauty }\end{array}$ & $\begin{array}{l}\text { Successful } \\
\text { and reliable } \\
\text { functioning } \\
\text { for desired } \\
\text { lifetime with } \\
\text { minimal use } \\
\text { of material } \\
\text { and } \\
\text { economic } \\
\text { resources. } \\
\text { Minimal } \\
\text { environ- } \\
\text { mental } \\
\text { impact, ease } \\
\text { of use and } \\
\text { aesthetically } \\
\text { pleasing } \\
\text { artifacts. }\end{array}$ & $\begin{array}{l}\text { Conclusions } \\
\text { that involve } \\
\text { the most } \\
\text { fundamental } \\
\text { material } \\
\text { components } \\
\text { in nature } \\
\text { inferred from } \\
\text { evidence } \\
\text { produced by } \\
\text { machines } \\
\text { and } \\
\text { amenable to } \\
\text { mathematical } \\
\text { descriptions }\end{array}$ & $\begin{array}{l}\text { Conclu- } \\
\text { sions that } \\
\text { support a } \\
\text { broad } \\
\text { theoretical } \\
\text { view of } \\
\text { human } \\
\text { behavior. }\end{array}$ & $\begin{array}{l}\text { Semanti- } \\
\text { cally } \\
\text { coherent } \\
\text { arguments } \\
\text { described in } \\
\text { elegant } \\
\text { prose. }\end{array}$ \\
\hline $\begin{array}{l}\text { Importance of } \\
\text { design }\end{array}$ & Major & minimal & minimal & modest \\
\hline $\begin{array}{l}\text { Professional or } \\
\text { vocational } \\
\text { associations }\end{array}$ & major & minor & minor & minor \\
\hline
\end{tabular}

\section{Summary}

We started with a brief review of the historical development of the academic disciplines which reveals that they are not purely epistemological in nature. Then, after considering the differences and similarities between engineering and science, we extended the analysis of Kagan to include 
engineering as a fourth culture. This led us to add two new dimensions, design and professionalism, to Kagan's analysis. At the end of the process, three central differences (which are obviously linked) arise that distinguish the engineering culture from the cultures of science, social science and the humanities.

- The key epistemological difference is that engineers are concerned with the institutional facts about material objects, in particular with their intended utilitarian purposes.

- Design plays an important role in engineering.

- Lastly, most engineers function outside of the university and because of this engineering education has vocational and professional purposes not found in the three dominant liberal arts cultures.

What does this say about the issue of an incorporation of engineering into the liberal arts as Duderstadt $^{8}$ among others has suggested? Of the 11 dimensions identified here, only one really seems to block an incorporation of engineering into a liberal arts framework and that is the dimension of professionalism. The other ten, which include all nine of those used by Kagan to subdivide the major accepted liberal arts, are just as applicable to engineering as they are to science, social science and the humanities. However, the usual separation of liberal education from professional education is an old and important one. It is a block that generates problems on both sides of this divide.

Perhaps the oldest tradition in academia is the bias inside the liberal arts against things useful for anything other than politics or scholarship. It can be tracked back into antiquity. There are those in the liberal arts world who worry about this subdivision. Menand, an English professor at Harvard, is highly critical of the tendency of liberal arts faculty to assume that the usefulness of things such as engineering, law and medicine rules them out as part of a liberal arts education and has suggested that the result is harmful to liberal arts students in various ways ${ }^{6}$. Matthew Crawford goes beyond this when he compares his life as the possessor of doctorate in political philosophy directing a think tank with his life as the owner and lead mechanic of a small motorcycle repair shop. Crawford concludes that he actually thinks more and is more liberated in the bike shop than in the think tank. ${ }^{12}$

On the other hand, engineering faculty usually run their programs as vocational programs. Almost everywhere we design programs which are designed to provide maximal specialization inside of one of a small set of conventional engineering disciplines. Suggestions that we should beef up our coverage of design and ethics are usually met with protestations about how much content we need to cover. This causes observers of the American college scene such as Andrew Hacker and Claudia Dreifus to view engineering in purely vocational terms and to clump engineering education with programs in hotel management and fashion merchandizing in their discussions. ${ }^{13}$ Inside the engineering world the result also is criticism that we are too focused on training, which is ultimately a commodity, and not focused enough on education. ${ }^{14}$ Engineering 
faculty have to come to grips with the reality that this degree is the last undergraduate degree the student is likely to receive and it should help prepare them to be more than cannon fodder for industry.

For engineering to join the liberal arts, attitudes need to change on both sides. There is no meaningful epistemological barrier.

\section{Acknowledgments}

The author thanks Chell Roberts, Adam Carberry and Shawn Jordan for useful discussions on the manuscript.

\section{Bibliography}

[1] Kagan, J. The Three Cultures: Natural Sciences, Social Sciences and the Humanities in the $21^{\text {st }}$ Century. Cambridge University Press, New York (2009)

[2] Snow, C.P. The Two Cultures and A Second Look Press Syndicate of the University of Cambridge, Cambridge (1964)

[3] Lucas, C.J. American Higher Education: A History, second edition, Palgrave Macmillan, New York (2006)

[4] Williams, D.E., “Morrill’s Act Contribution to Engineering”, The Bent of Tau Beta Pi (2009)

[5] Grayson, J.O., The Making of an Engineer, John Wiley \& Sons, New York (1993)

[6] Menand, L. The Marketplace of Ideas: Reform and Resistance in the American University W.W. Norton \& Company, New York, (2010)

[7] Changing the Conversation, Committee on the Public Understanding of Engineering of the National Academy of Engineering, The National Academies Press, Washington D.C. (2008)

\{8] Duderstadt, J. J. Engineering for a Changing World: A Roadmap for the Future of Engineering Practice, Research and Education. The Millenium Project. Ann Arbor, MI: University of Michigan (2008).

[5] Searle, J.R. The Construction of Social Reality Simon and Schuster (1997)

[10] Coleman, L. Liz Coleman's Call to Reinvent Liberal Education from TED: Ideas Worth Spreading (2009) http://www.ted.com/talks/lang/en/liz_coleman_s_call_to_reinvent_liberal_arts_education.html

[11] Ohlund, M., Sheppard, S.D., Lichtensten, G., Eris, O., Chachra, D. and Layton, R.A. "persistence, Engagement and Migration in Engineering Programs”, Journal of Engineering Education 97(30, 259-278 (2008)

[12] Crawford, Matthew B., Shop Class as Soulcraft, Penguin Books, New York (2009)

[13] Hacker, A., \& Dreifus, C. Higher Education? New York, New York: Holt/Times Books (2010).

[14] Flowers, Woodie, presentation at Engineer of the Future Summit, Olin College, (2009) http://www.youtube.com/watch?v=F84LtXvLTtA 


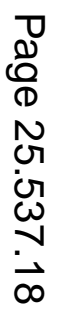

